\author{
ZDZISŁAW KŁECZEK*, ZYGMUNT NIEDOJADŁO**, EDWARD POPIOŁEK**, \\ WOJCIECH SKOBLIŃSKI***, PAWEŁ SOPATA**, TOMASZ STOCH**, \\ ARTUR WÓJCIK**, DAGMARA ZELJAŚ*
}

\section{MINING HAZARDS ANALYSIS WITH SIMULTANEOUS MINING COPPER ORES AND SALT DEPOSITS IN LGOM (LEGNICA-GLOGÓW COPPER BELT) MINES WITH REGARD TO DYNAMIC INFLUENCES}

\section{ANALIZA ZAGROŻEŃ GÓRNICZYCH PRZY RÓWNOCZESNEJ EKSPLOATACJI ZLOŻA RUD MIEDZI I ZLOŻA SOLI W KOPALNIACH LGOM W ZAKRESIE WPLYWÓW DYNAMICZNYCH}

In the case of locating two bedded deposits of different mineral resources in a small vertical distance, additional or increased mining hazards can occur (deformations of the rock mass, crumps and mining shocks, hazards to the land surface). This paper has thoroughly examined the impact of exploitation of the lower-located deposit of copper ore on the higher-located deposit of salt as well as the reverse situation as regards the dynamic phenomena, being the greatest lithospheric hazard in LGOM. At the same time theoretical models of processes were applied, verified by previous observations in situ in mines of Legnica-Głogów Copper Belt.

Keywords: mechanics of the rock mass, mining hazards, deformations of the rock mass, forecasts of mining impact, shocks of the rock mass

W przypadku usytuowania dwóch pokładowych złóż różnych surowców mineralnych w niewielkiej odległości pionowej mogą występować dodatkowe lub zwiększone zagrożenia górnicze (deformacje górotworu, tąpania i wstrząsy górnicze, zagrożenie powierzchni terenu). W pracy rozważono wszechstronnie oddziaływanie eksploatacji niżej zalegającego złoża rudy miedzi na wyżej zalegające złoże soli kamiennej oraz sytuację odwrotną w zakresie zjawisk dynamicznych, będących największym zagrożeniem litosferycznym w LGOM. Wykorzystano przy tym modele teoretyczne procesów, zweryfikowane przez dotychczasowe obserwacje in situ w kopalniach Legnicko-Głogowskiego Okręgu Miedziowego.

Slowa kluczowe: mechanika górotworu, zagrożenia górnicze, deformacje górotworu, prognozy wpływów górniczych, wstrząsy górotworu

* INSTITUTE OF INNOVATIVE TECHNOLOGIES EMAG, UL. LEOPOLDA 31, 40-189 KATOWICE, POLAND

** AGH UNIVERSITY OF SCIENCE AND TECHNOLOGY, AL. MICKIEWICZA 30, 30-059 KRAKÓW, POLAND

**** KGHM POLSKA MIEDŹ S.A., UL. M. SKŁODOWSKIEJ-CURIE 48, 59-301 LUBIN, POLAND 


\section{Introduction}

If mining is conducted in one region at two levels, we face a mutual interaction between these operations. In the event when this operation concerns the same deposit, for example two or more coal beds, the problems of mutual hazards have already been recognized to a significant extent. The ways of predicting the scale of hazards has been worked out and, first of all, it is known how to use prophylactic actions protecting against excessive mutual influences.

This is different in cases when there are operations conducted in one area where two kinds of permanent deposits of mineral raw materials. Such is the case in the Legnica-Glogów Copper Belt where over the deposit of copper ore there is a rock salt deposit which, as reconnaissance works indicate, can be economically extracted. Currently formal preparations are in the final stage (the licence) and technical ones for conducting organized mining exploitation of salt deposits by use of the pillar-compartment method.

It is designed to intensively extract copper ores deposits at the same time, as the salt extraction is conducted vertically at depths between 30 and $120 \mathrm{~m}$. Hence, this is the situation where we can find running operations simultaneously influencing each other. It creates additional hazards for mining headings, area surface and, first of all, for the safety of people. It is important in this case to forecast mutual interactions, setting zones of hazard and, first of all, appropriately coordinate the mining works in particular deposits.

The solution of the problem set under specific conditions of the mining region required preparation of the methods of forecasting shifts, deformations and stresses in exploited deposits and their use in the analyses of mutual interactions.

When implementing the work, previous good knowledge of the course of dynamic phenomena in the rock mass and the distribution of stresses in LGOM was used. In their deliberations the authors have used verified theoretical models in LGOM related to the distribution of stresses around mining headings and shifts and deformations of the rock mass caused by the creation of voids in the rock mass. They have used also their own vast experience with shaping fields shifts, deformations and stresses in the rock mass and mining shafts (Popiołek \& Kłeczek, 2011, 2012).

In this publication main considerations are presented with regard to dynamic influences on mine workings and hazards resulting from them. The influences of impacts and hazards resulting from the processes of shifts and deformations of the rock mass will be presented by the Authors in a separate publication.

\section{The Elements of Geological Structure Having Effect on Dynamic Phenomena}

Bearing in mind that geological conditions of the region of LGOM are well recognised and described for instance, in the Monograph of LGOM (2007), the authors present in this chapter only this information that has direct importance in analyses and forecasts of dynamic phenomena present in the rock mass. This applies to the layers surrounding the deposit of salt and the deposit of copper ores. 


\subsection{Layout and the Presence of Layers}

In the rock mass in the whole area of LGOM one can identify three seperate complexes of rocks that stand out in terms of the period of their creation and geomechanical properties:

- A complex of crystalline rocks from the proterozoic age and rocks from the old Paleozoic (monocline base),

- A complex of sedimentary rocks from perm-Mesozoic (rocks building monocline),

- A complex of tertiary deposits and Cenozoic ones constituting monocline cover.

\begin{tabular}{|c|c|c|c|c|}
\hline \multirow{2}{*}{$\begin{array}{c}\text { The scope of } \\
\text { depth [m] }\end{array}$} & \multicolumn{4}{|c|}{ Profile } \\
\hline & & Stratigraphic & Layer description & Aquifers \\
\hline $0-62$ & & Quaternary & grounds & \\
\hline \multirow{2}{*}{$62-439$} & \multirow{2}{*}{\multicolumn{2}{|c|}{ Tertiary }} & \multirow{2}{*}{$\begin{array}{c}\text { sands, loams and } \\
\text { brown coal }\end{array}$} & \\
\hline & & & & from ca. $380 \mathrm{~m}$ \\
\hline $439-546$ & \multirow{2}{*}{$\begin{array}{l}\cdot \frac{0}{N} \\
\tilde{N} \\
\cdot \frac{\pi}{2} \\
F\end{array}$} & $\begin{array}{c}\text { middle variegated } \\
\text { sandstone }\end{array}$ & sandstones & \\
\hline $546-750$ & & $\begin{array}{l}\text { lower variegated } \\
\text { sandstone }\end{array}$ & $\begin{array}{l}\text { sandstones, } \\
\text { clay-slates }\end{array}$ & \\
\hline $750-764$ & \multirow{7}{*}{$\frac{\varepsilon}{\grave{Q}}$} & zechstein P4 & shale & \\
\hline \multirow{3}{*}{$764-852$} & & \multirow{3}{*}{ zechstein P3 $\div$ P2 } & \multirow{3}{*}{$\begin{array}{l}\text { gypsum, breccia } \\
\text { anhydrite dolomite }\end{array}$} & to ca. $775 \mathrm{~m}$ \\
\hline & & & & \\
\hline & & & & from ca. $810 \mathrm{~m}$ \\
\hline $852-893$ & & \multirow{3}{*}{ zechstein P1 } & upper anhydrite & \\
\hline $893-1010$ & & & rock salt & \\
\hline $1010-1071$ & & & $\begin{array}{l}\text { anhydrite lower } \\
\text { lime, dolomite }\end{array}$ & \\
\hline from 1071 & & Rotliegend & sandstones & \\
\hline
\end{tabular}

Fig. 1. Characteristic stratigraphic-hydro-geological profile O.G. „Sieroszowice I“

Figure 1 presents a characteristic stratigraphic-hydrogeological profile of the regional mining activities in the deposit of salt.

The base of the copper deposits is from the lower Permian in the form of a more than $400 \mathrm{~m}$ complex of dense rotliegend sandstones.

The primary deposit of copper ore is present in the lowest level of zechstein made of limestones and dolomites with the thickness from $5 \mathrm{~m}$ to $70 \mathrm{~m}$, over which there are formations of basic anhydrite with a thickness of $10 \div 30 \mathrm{~m}$. Above in the carbonate rocks there are layers of the stone salt, among which the oldest salts, older salts and the youngest salts are differentiated. The thickness of salt layers increases towards the north, along with the collapsing of zechstein layers.

Over the deposit of salt there are formations of Triassic represented by formations of bundsandstein constructed with variable thickness of layers of anhydrite claystone, carbonate rocks in the form of main dolomite and basic anhydrite. The thickness of bundsandstein is variable and ranges from 44 to $479 \mathrm{~m}$, with an average of approx. $270 \mathrm{~m}$.

Tertiary with a thickness from 250 to $450 \mathrm{~m}$ is represented by glauconite sands and quartz, muds, mudstone, shales, marls, dolomites and gypsum. Quaternary with a thickness of approximately $50 \mathrm{~m}$ is composed of moraine and river deposits. 


\subsection{Rock Salt Deposit}

The rock salt deposit in LGOM has an extent direction NW-SE and lingers at depths of approximately from $765 \mathrm{~m}$ to approximately $1220 \mathrm{~m}$. The thill surface shows a clear morphological diversity with height differences of approximately $50 \mathrm{~m}$, sometimes $150 \mathrm{~m}$. The ceiling of salt deposits is much less differentiated. It is deposited in the depths from around 745 to approximately $1040 \mathrm{~m}$ and occurring height differences are contained within $20 \mathrm{~m}$ and exceed $50 \mathrm{~m}$ only incidentally.

The average thickness of salt deposits in the field of O G. „Sieroszowice I“ is approx. $70 \mathrm{~m}$ and the largest is approximately $186 \mathrm{~m}$. The deposit is directed towards NE at the angle of $3 \div 6$ degrees and it is accompanied by growth in the thickness of salt.

\subsection{The Deposit of Copper Ores}

The deposit of copper ores in LGOM is a one layer deposit located between 30 and $120 \mathrm{~m}$ below the salt deposits. Throughout the entire area, under the estimated mine workings, this is the deposit of the industrial worth. The expected operational wicket varies from $2.0 \mathrm{~m}$ to $2.7 \mathrm{~m}$. The deposit of copper ore has already been the object of mining exploitation for many years.

\section{Mining Hazards in LGOM}

In geological-mining conditions that occur in the Legnica-Glogów Copper Belt, there are numerous mining hazards and the most important are:

displacement and deformations of the rock mass and surface area related to establishing post-mining voids (deformations of the rock mass and area surface),

mining tremors and rock bursts resulting from the concentration of stresses and elastic energy accumulation in the deposit and rocks surrounding mining works (dynamic influences).

\subsection{Deformations of the Rock Mass and Area Surface}

The creation of post-mining voids in the rock mass initiates the shifts of the rock mass towards a selected space where the sizes depend on the thickness of the exploited deposit, the method of filling in voids, as well as on the exploitation system. Over the exploited deposit, with the collapse systems, a collapse and crack zone is created reaching on average no higher than 10-12 of the thickness of exploited layer. Above this zone, this phenomenon is usually of regular subsidence basin character moving towards the surface of the area and increasing its horizontal range. All mining works, chambers and shaft sections within subsidence basin will be affected by shifts and deformations which may result in the hazards for their functioning. (Popiołek, 2009; Florkowska, 2000)

\subsection{Dynamic Influences}

Rapid discharge of previously accumulated elastic energy in the rock mass can cause rock bursts in the mining works and paraseismic phenomena (shocks of the rock mass) in the form of weak earthquakes. They are, in the conditions of LGOM, the most serious mining hazards 
which are affected by the large depth of mining exploitation (often beyond $1000 \mathrm{~m}$ ) and the presence of rigid and very resistant layers of dolomite, limestones and anhydrite in the ceiling of the deposit of copper ores. In the case of conducting mining activities in 2 deposits (salt and copper ore) located in a small vertical distance, the hazard of dynamic influences may increase which requires special attention.

In this study, as was previously mentioned at the beginning, we will present problems related to dynamic hazards.

\section{The Stability of Mine Workings in the Deposit of Salt}

Running at the same time, the mining exploitation of one deposit located just under another one is happening in Poland for the first time and is unique in the world of mining. It required that the Authors to prepare a new methodology for analyses and forecasting mining hazards adequate for the existing geological-mining conditions.

In order to assess the degree of additional hazards of loss of stability of mine workings made in the deposit of salt, resulting from the deposit mining of copper ores, their current stability has been determined relying on previous recognition of geo-mechanical parameters of the rock mass of salt (Zeljaś, 2008). Taking into account that:

- the average depth of the ceiling foundation of mine working $H$ is approx. $952 \mathrm{~m}$,

- the most unfavourable safety coefficient $n=1$,

- volumetric weight of overlaying rocks $\gamma_{n}=0,025 \mathrm{MPa} / \mathrm{m}$,

- immediate resistance to rock compression located in a side wall of the working $R_{c}=34,42 \mathrm{MPa}$,

- the width of workings neighbouring with a pillar $l_{1}=l_{2}=8 \mathrm{~m}$,

The minimum width of the resistance pillar can be determined (Popiołek \& Kłeczek, 2011):

$$
f=3,7 n \sqrt{\frac{y_{n} H}{R_{c}}}\left(\sqrt{I_{1}}+\sqrt{I_{2}}\right)
$$

it is: $f=17.4 \mathrm{~m}$

Based on the results of observations, one can state that the real resistance pillar has a minimum width of $23 \mathrm{~m}$ and thus it meets the stability condition for the safety factor at a level 1.487.

In order to verify the assessment of the stability of mine workings, local inspectors were dispatched to assess salt workings in the G-55 O/ZG "Polkowice - Sieroszowice" branch. As a result, it was confirmed that generally the stability condition of salt workings is met. In several cases, however, there were symptoms of loss of stability within mining pits. It was influenced by tectonic disorders in geological construction of salt deposit, inter-beddings and anhydrite inserts as well as technical omissions in a continuous control of the condition of salt workings that required removing loose pieces of cracked and loosened strata of the rock mass (Popiołek \& Kłeczek, 2011). 


\section{Impact of Mining of Rock Salt on Operational Excavations in the Deposit of Copper Ores}

\subsection{Vertical and Horizontal Range of Impact of Salt Workings}

The basis for the discussion to identify the vertical and horizontal range of impact of salt workings was the determination of the secondary stress state in the vicinity of these headings. The classical method to proceed in such cases is to define the stress state by analytical solutions (Korman, 1958).

In the case of lack of additional tectonic impacts, the primary state of stress in the rock mass intact by mining activities is defined as:

- primary vertical pressure:

$$
p_{z}=\gamma H
$$

- primary horizontal pressure:

$$
p_{x}=p_{z} \frac{v}{1-v}
$$

where $v$ - Poisson's coefficient.

The creation of a mines working violates the initial balance of the rock mass and contributes to the creation of the secondary stress state. On the contour of a mine working there is a concentration of stresses compressing the side walls, extending the ceiling and thill and cutting the corners. According to the solution by G.N. Sawin and A. B. Morgajewski (Kłeczek, 1994) in the vicinity of a mine working with rectangular section (of the chamber) with the height $\mathrm{w}$ and width 1 (Fig. 2) the maximum values of stresses are:

- in the side walls:

$$
\begin{gathered}
\sigma_{x}=0 \\
\sigma_{z}=\sigma_{z \max }=p_{z}(1+\alpha)-p_{x}
\end{gathered}
$$

- in the ceiling and thill:

$$
\begin{gathered}
\sigma_{x}=\sigma_{x \max }=p_{x}(1+\beta)-p_{z} \\
\sigma_{z}=0
\end{gathered}
$$

where $\alpha, \beta$ determines the coefficients of shape dependent on the ratio of breadth of a mine working 1 to its height in.

The value of shape coefficients $\alpha, \beta$ are specified in Table 1 .

The value of shape coefficients $\alpha, \beta$

\begin{tabular}{|c|c|c|c|c|c|c|c|}
\hline \hline$l / w$ & 50.00 & 20,00 & 5.00 & 1.00 & 0.20 & 0.05 & 0.02 \\
\hline$\alpha$ & 17.00 & 4.00 & 2.00 & 0.84 & 0.20 & 0.02 & 0.01 \\
\hline$\beta$ & 0.01 & 0.02 & 0.20 & 0.84 & 2.00 & 4.00 & 17.00 \\
\hline
\end{tabular}


The rock mass of salt at greater depths remains under exposure to high primary stresses. The conducted mining activities provoke the formation of changes which can affect the emergence of stresses within the exploited headings. Shelves and pillars, as protective units in the immediate vicinity of chambers, are subjected to intensive deformation processes which can lead to local destruction zones.

The analysis of the stability of a natural barrier left in the ceiling of the deposit in the form of a shelve has been made on the basis of the theory by K. Terzaghi which examines the balance of the element of the rock mass with the width equal to the width of a mine working $l$ and its thickness $d z$ (Fig. 2).

The examined element of the rock mass is in a static balance under the influence of the following forces:

- in the vertical direction:

- overburden stress, $\sigma_{z} l$

- base reaction, $\left(\sigma_{z}+d \sigma_{z}\right) \cdot l$

- own weight, $l \cdot \gamma \cdot d z$

- forces of internal consistency, $k d z$

- in the horizontal direction:

- forces of side pressure, $\sigma_{x} d z$

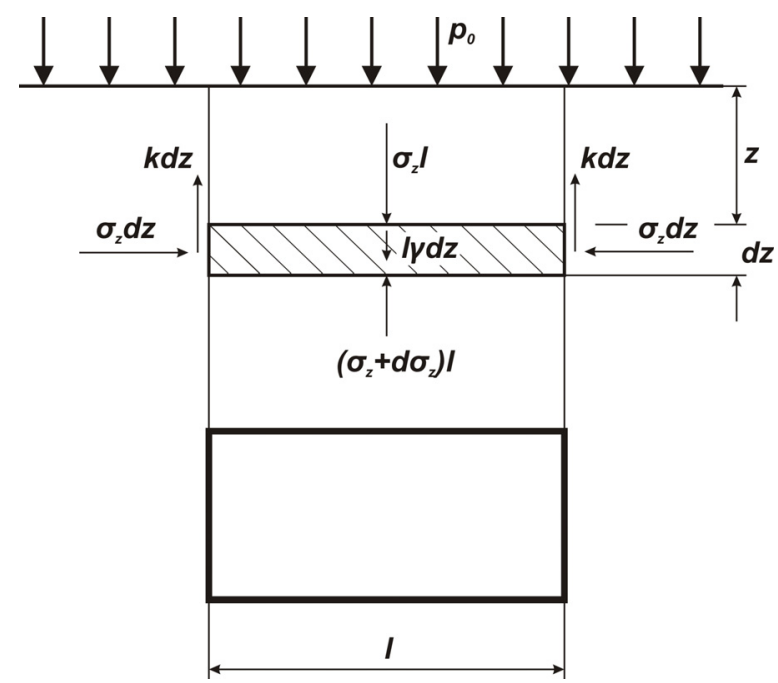

Fig. 2. Diagram of the stress of the ceiling in a rectangular mine working in the light of the theory by K.Terzaghi

The theory of K.Terzaghi allows for determination of vertical stress within the ceiling of a mine working (of the chamber) as:

$$
\sigma_{z}=\frac{\frac{i \gamma}{2}-k}{A_{n} \operatorname{tg} \rho}\left(1-e^{-\frac{2 A_{n} \operatorname{tg} \rho}{l} z}\right)+p_{0} e^{-\frac{2 A_{a} \operatorname{tg} \rho}{l} z} \leq \frac{R_{c}}{n}
$$


where: $A_{n}=\operatorname{tg}^{2}\left(45^{\circ}-\frac{\rho}{2}\right)$, and:

$\gamma$ - Average volumetric weight of salt deposit overburden,

$k$ - Cohesion of salt rock,

$\rho$ - Internal friction angle of salt rock,

$l$ - The width of a mine,

$A_{n}$ - The coefficient of horizontal expanding,

$R_{c}$ - Immediate resistance of salt to compression,

$n$ - The safety coefficient.

Based upon the data concerning the mining of salt in O G. "Sieroszowice" (Andrusikiewicz, 2012), an analysis has been conducted regarding the stress state within scheduled mine workings. In the deliberations they adopted model of a three level field of exploitation (Fig. 3).

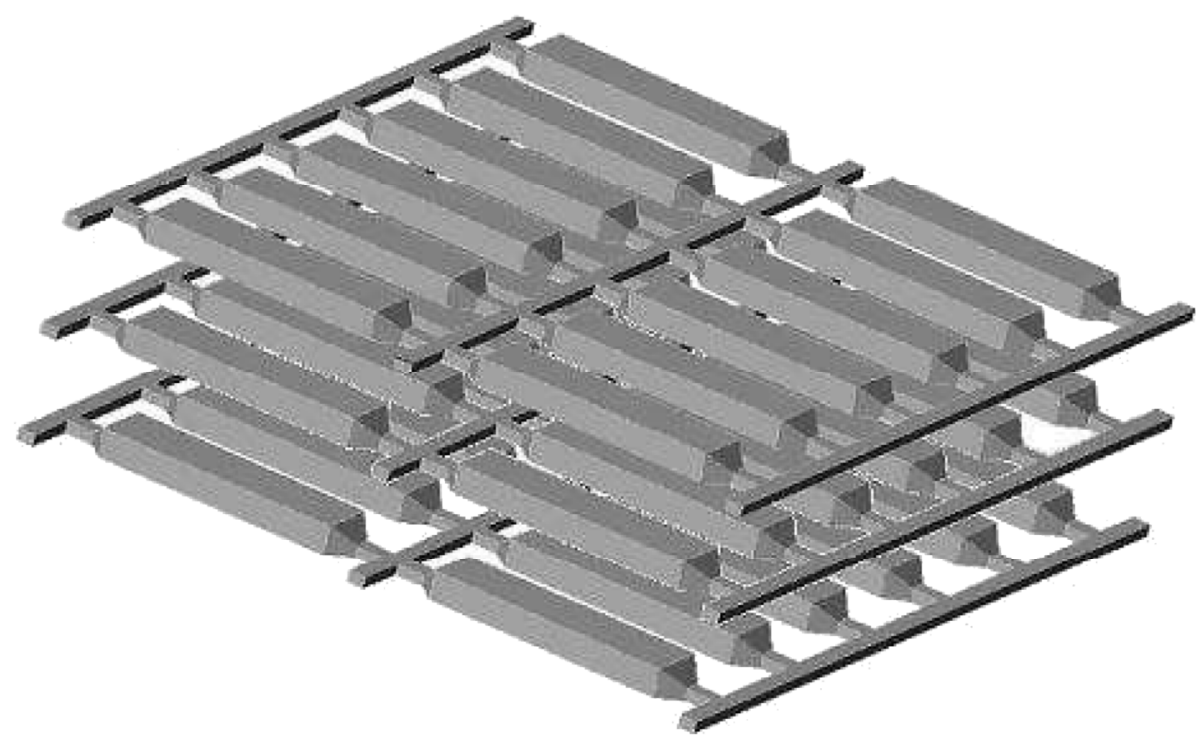

Fig. 3. The project of the spatial layout of mining chambers

The thickness of a shelve left in the deposit of salt above the exploitation chambers has been verified by analytical calculations in accordance with the assumptions of the theory by Terzaghi specifying that it cannot be smaller than $30 \mathrm{~m}$. Taking into account the hydro-geological safety conditions and the possibility of local cracks as well as the previous structure of making deposits available, it is assumed for design purposes to leave a protective area in the ceiling of the deposit with a thickness of $p_{\text {str }}=30 \mathrm{~m}$.

On the other hand, owing to the effective protection of separating layers of rock salt from the copper ore layer lingering below, the thickness of a thill shelve cannot be smaller than $15 \mathrm{~m}$. For a specific location and the analyzed characteristic geological profile of the deposit, for further analyses, a thill shelf with the thickness of $p_{s p}=15 \mathrm{~m}$ has been adopted. 
Figure 4 presents a section through elementary operations field, adopted as basic for detailed analyses.
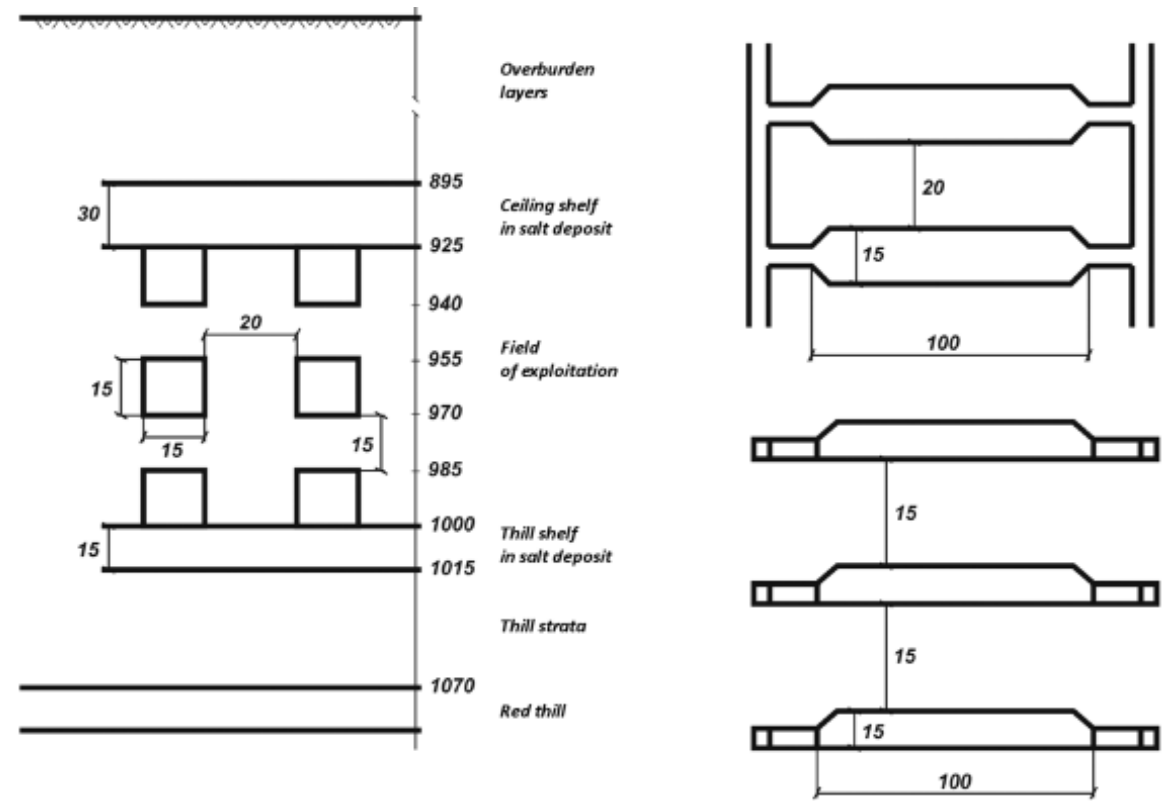

Fig. 4. The scheme of the elementary field of exploitation of salt deposits by chamber-pillar system with marked dimensions

Based on the solutions by G.N. Sawin and A. B. Morgajewski (templates 4, 5 and 6), the state of stress on the contour of a mine chamber working and in its vicinity has been defined (Popiołek \& Kłeczek, 2011). The vertical and horizontal ranges of impact on salt workings are defined in the ceiling of the field of exploitation, side wall of the middle level of the field of exploitation and thill of the field of exploitation. For instance the distribution of stresses in the thill of the operational chamber is presented in Figure 5.

Theoretical templates, assuming homogeneity and isotropy of the rock mass, give only an approximate, in relation to reality, image of the stress state that is present in the rock mass in the vicinity of a completed mine working. In order to specify more precisely the range of the exploitation headings, numerical methods should be reached for.

The analysed numerical model used the disc of the rock mass with mine workings in the deposit of salt (chambers). The disc reached to the top part the land surface while in the lower part it included the layers of rotliegend. The disc was defined in such a way, and had the following dimensions: height: $1200 \mathrm{~m}$, width: $2000 \mathrm{~m}$.

On the lower edge of the disc and on both side edges, proper movement conditions have been assumed. On the lower edge zero vertical movement has been assumed, while on side edges of the model zero horizontal movements were assumed.

The disc was encumbered with its own weight resulting from gravitational field and the assumed geo-mechanical parameters typical for particular layers in a geological profile. 


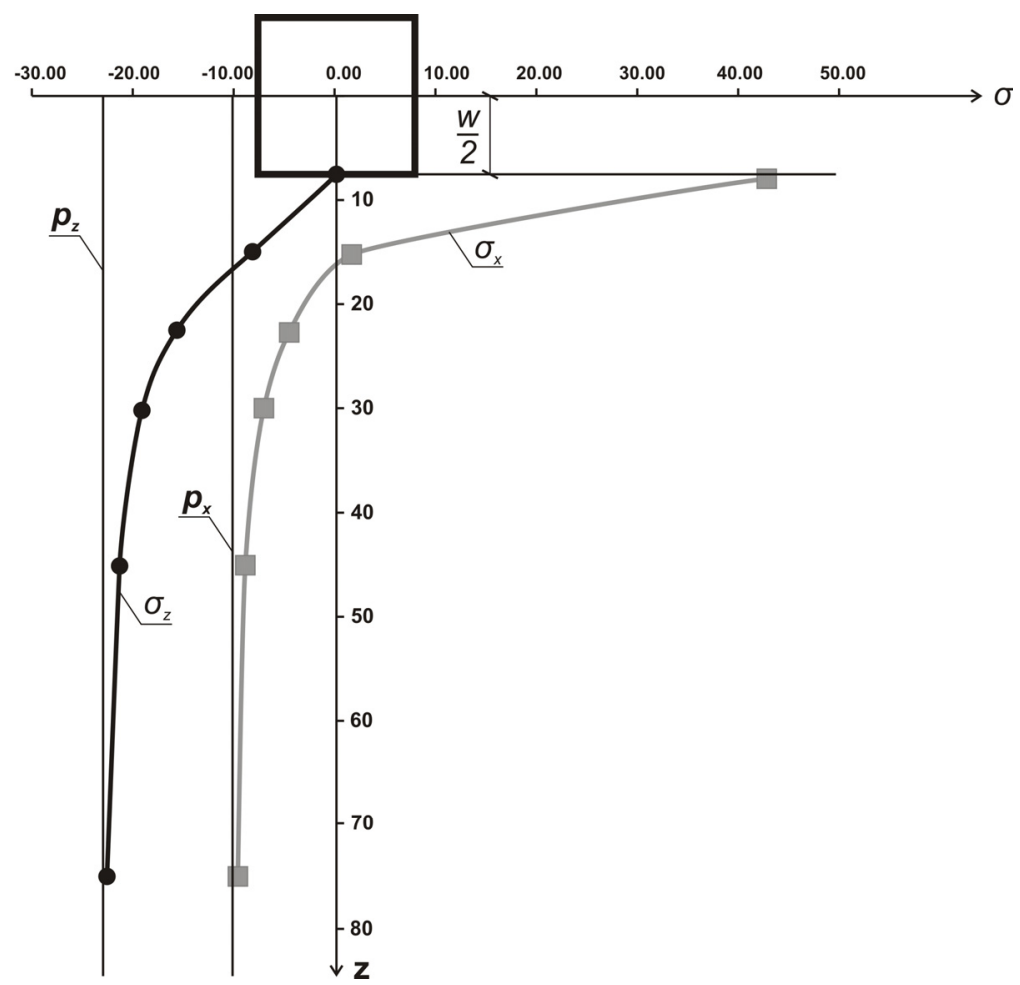

Fig. 5. The distribution of stresses in the thill of the operational chamber

As a result of numerical calculations and based on solutions adopted in the PZZ project for exploiting conditions of salt deposits, it was specified that the increased state of vertical stresses which may have impact on mine workings in the copper deposit reaches up to $70 \mathrm{~m}$ below the thill of salt chambers. At the same time, with regard to horizontal stresses this scope is smaller and is approx. $50 \mathrm{~m}$ from the side walls of the exploitation field.

In the above deliberations the border for increased stresses is the coefficient 0.9 , so it is practically a primary state of pressures of the rock mass.

\subsection{The Forecast of Stresses in the Rock Mass at the Level of the Deposit of Copper Ores from the Planned Mining of Salt}

As was presented in the previous chapter, the distribution of increased stresses around the planned headings in the deposit of salt is the function of distance respectively from the ceiling, the side walls as well as and thill of a mine working (mining chamber of salt).

The above changes can affect the structure of the strata of the rock mass, constituting the direct ceiling of the exploitation headings of the deposit of copper ores. As a result there is a possibility of a possible loss of stability of the ceiling shown as an increased frequency of local rocks collapsing in roof-rocks. A significant element for the problem of salt exploitation impact on mining fields in the deposit of copper ores is the distribution of stresses both vertical and 
horizontal below the thill of the chambers at the lowest level (the third) of salt exploitation. The considerations relate to the whole area within the boundaries of the licence for the recognition of rock salt deposit. However, in accordance with the information contained in the study (Popiołek \& Kłeczek, 2012), the analysis concerning the methodology of salt exploitation currently includes only the area of the so-called salt deposits "Bądzów" which correspond to the southern part of the licensed region, from the side of the SW-1 shaft (Fig. 6). If salt exploitation is to be conducted on an industrial scale in years to come, it is only in this area.

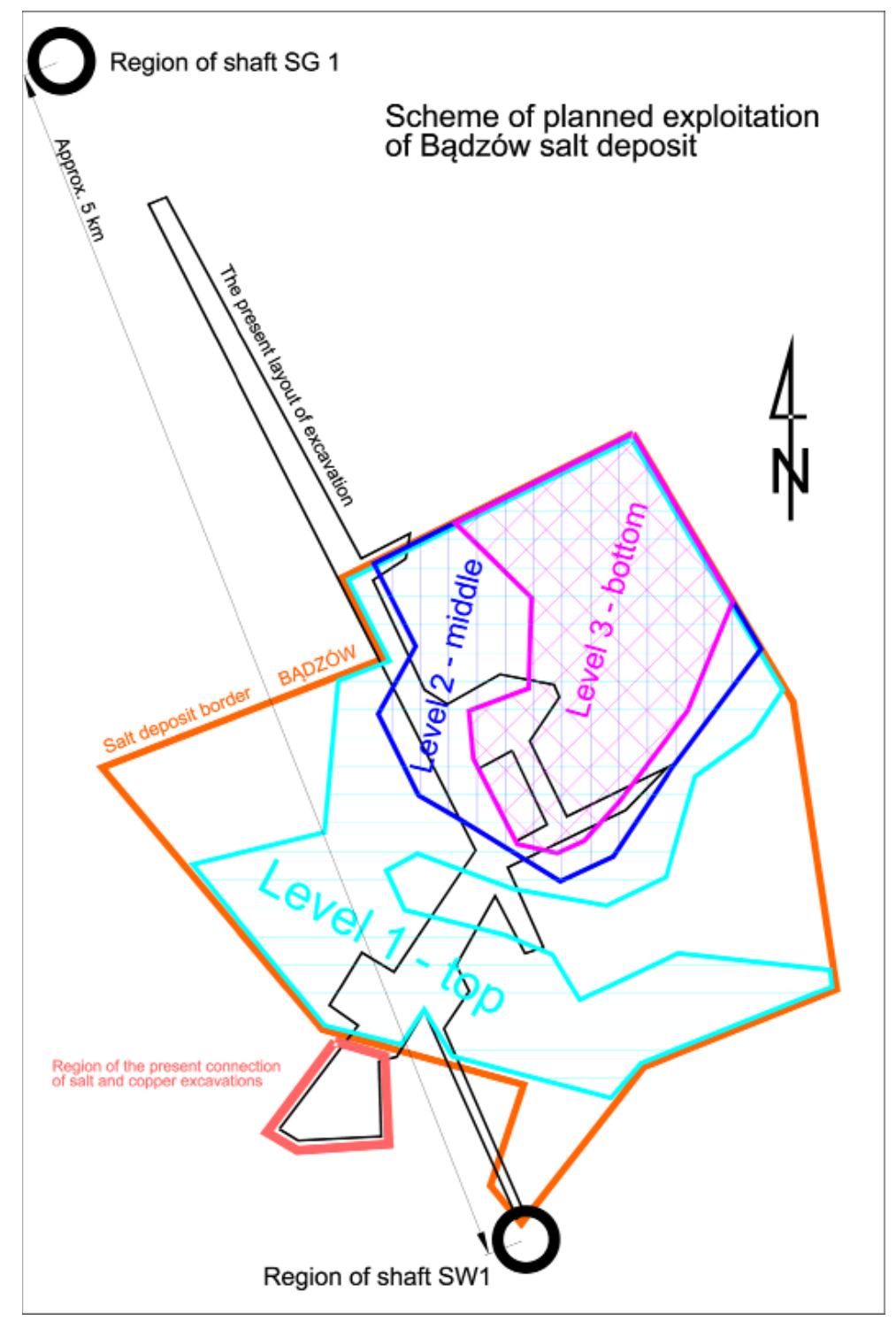

Fig. 6. Boundaries of the deposit "Bądzów" and a project of exploitation levels 
Based on the map documentation of the deposit of copper ore and the deposit of salt in the area anticipated to obtain the concession for exploitation of the deposit of salt ("Bądzów" deposit) the following has been drawn up:

- a stratification map of the height of deposition of the excavation ceiling in the deposit of copper ore,

- a stratification map of the floor of the deposit layer of rock-salt.

Based on both maps, the isolines map was then drawn up of vertical distance between the ceiling of the deposit of copper ores and the floor of designed, the lowest-located salt excavations (Fig. 7). In this manner the bottom shelf was taken into account in the deposit of salt of the value of $10 \div 15 \mathrm{~m}$, which is expected to increase safety as regards exploitation of both of these deposits. Figure 7 presents zones of possible dynamic impacts from the exploitation of the deposit of salt in connection with the exploitation project of the deposit of copper ore according to valid concession to 2063 .

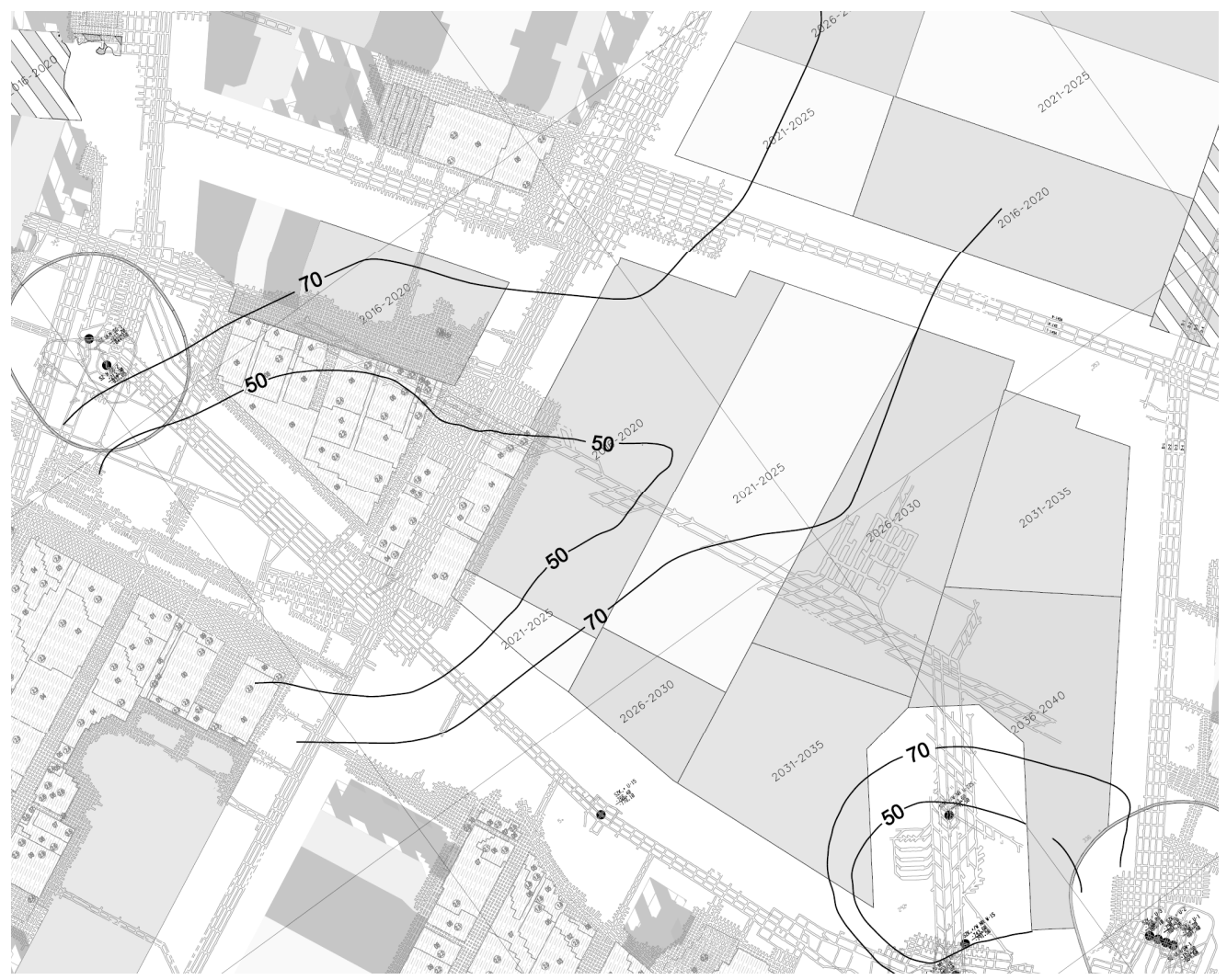

Fig. 7. The exhausting map of the deposit of copper ores until 2063 in the area of the deposit of salt "Bądzów" with outlined zones of possible geodynamic impacts from exploitation of the deposit of salt on exploitation of copper ore 
Analysing the isolines maps of the distance between the deposits and designs for further exploitation of the deposit of copper ores obtained it is stated that:

- only in the northern part of the area of the deposit of "Bądzów" from the western side the distance between the deposits is from $50 \mathrm{~m}$ to $70 \mathrm{~m}$ (Fig. 7),

- until 2016 it is not planned to use up the deposit of copper ore in the area of the deposit of salt „Bądzów“. After 2016, however, mutual interactions can occur, requiring proper coordination when planning the fields of exploitation.

Summing up this analysis, it needs to be stated that in the case exploitation of the deposit of salt will be made before exploitation of the deposit of copper ore, it will not constitute a more significant hazard for excavations of ore in terms of stability of ceiling layers.

\section{Impact of Mutual Interactions of Exploitation of the Deposit of Copper Ore and of the Deposit of Rock-Salt on Dynamic Phenomena and the Possibilities to Limit Them}

\subsection{Dynamic Phenomena in Copper Ores Mining}

Previous experiences from carrying out mining exploitation in O G. "Sieroszowice" and O.G. "Polkowice" suggests that existence of crumps in copper ores mining is a symptom of the dynamic processes taking place in the rock mass, caused by both natural factors, and technical and exploitation factors, resulting from the process of extracting useful minerals. The following are the most important among the natural factors:

- high compressive strength of carbonate rocks, ability to accumulate elastic strain energy and tendency to suddenly discharge thereof, and also high thickness of complex of carbonate and anhydrite rocks lying in the direct ceiling of the deposit,

- deposition in the floor of Weissliegendes sandstone of variable strength,

- high deposition depth of the deposit,

- tectonic involvement of the deposit.

In order to characterise in detail the crumps hazard description was presented of seismicity of the rock mass of LGOM against a background of obtained there extraction in 2002-2011 (Fig. 8).

As it results from the numerical data presented, the seismic activity of the rock mass is diversified in the area of O.G. "Sieroszowice", where there is a need to determine mutual influences of exploitation of the deposits of copper and salt. If in the period analysed (over the last 10 years) in the whole area of LGOM at average extraction equal to $31.210^{6} \mathrm{Mg} /$ year, where annually 697 shocks occurred that generated energy of 3.6 GJ/year, then in O.G. "Sieroszowice I" with an average extraction of ore equal to $6.4510^{6} \mathrm{Mg} /$ year, annual energy expenditure of the rock mass shocks was equal to $0.1 \mathrm{GJ} /$ year. Translating it into a more legible index, it can be stated that exploitation of copper ores in LGOM in all mines of KGHM Polska Miedź S.A extraction equal to $106 \mathrm{Mg} /$ year is accompanied by the rock mass shocks of energy expenditure equal to $0.115 \mathrm{GJ} /$ year. However, in O.G. "Sieroszowice" extraction of $10^{6} \mathrm{Mg} /$ year of ore annually releases energy of $0.014 \mathrm{GJ} /$ year, clearly smaller than average for LGOM. 


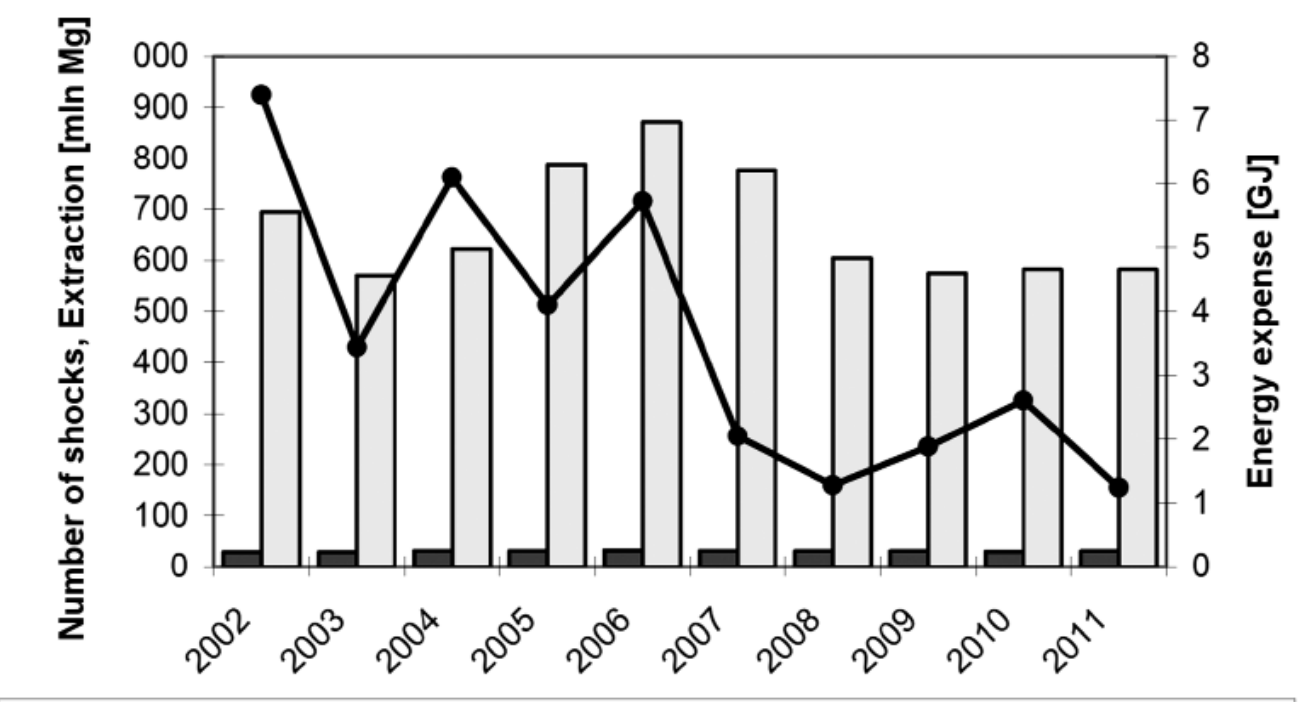

Extraction [m/n Mg] $\square$ Number of shocks

Energy expense [GJ]

Fig. 8. Extraction and seismic activity of the rock mass of LGOM in 2002-2011

\subsection{Mutual Interactions of Exploitation of the Deposit of Copper and of the Deposit of Rock-Salt on Dynamic Phenomena}

Previous experiences from carrying out exploitation in O.G. "Sieroszowice" suggests that:

- the high deposition depth of the deposit of copper ores is the reason for substantial primary pressures of the rock mass, which is of fundamental importance for the amount and the concentration of the condition of secondary stresses and for nature and course of dynamic phenomena by which exploitation is accompanied,

- the relatively small thickness of the deposit of copper ores amounting to $2 \div 3 \mathrm{~m}$, maximally $4 \mathrm{~m}$, is a favourable factor from the point of view of potential dynamics of the rock mass deformation processes,

- the thickness of compact layers of the basic ceiling, including of carbonate rocks at the level of $5 \div 10 \mathrm{~m}$ and anhydrites from 25 to $75 \mathrm{~m}$, preceding a package of salt layers $(100 \div 180 \mathrm{~m})$ and upper anhydrites lying over the deposit of salt, is of certain importance for development of dynamic processes. In contacts zones between these lithological centres, in particular on the contact of anhydrites and rock-salt, delamination can occur,

- the layered construction of the rock mass justifies adoption of the assumption that it consists of a number of slabs of rock with thicknesses resulting from natural separations of particular banks. Not only deformability of component layers determines deformations of this type of structure, but also strength of the binder between the rock mass layers.

In Figure 9 an adequate for the region of the deposit of salt in the field "Bądzów" layer and block physical model of the rock mass is presented. It finds its justification at geo-mechanical 
analyses of phenomena taking place in mines of LGOM, since this model is composed of three fundamental and cooperating groups of elements:

- the floor, made of a layer of limited thickness of a relatively strong grey sandstone, lying on a very thick layer of sandstone of red sill piece, demonstrating a high level of deformability and a low level of strength,

- the deposit of copper ores treated as a structure remaining in a pre-critical condition (undisturbed soil, pillars) or as technological pillars working in the post-critical phase,

- the ceiling treated as a pile of rocks touching each other through the contact surfaces, which enable mutual shift of neighbouring rocks, or formation of delamination. This delamination will occur especially on the boundaries of rock centres of different mechanical rigidity $\boldsymbol{E} \boldsymbol{J}_{\boldsymbol{n}}$ and thicknesses $\boldsymbol{H}_{\boldsymbol{n}}$.

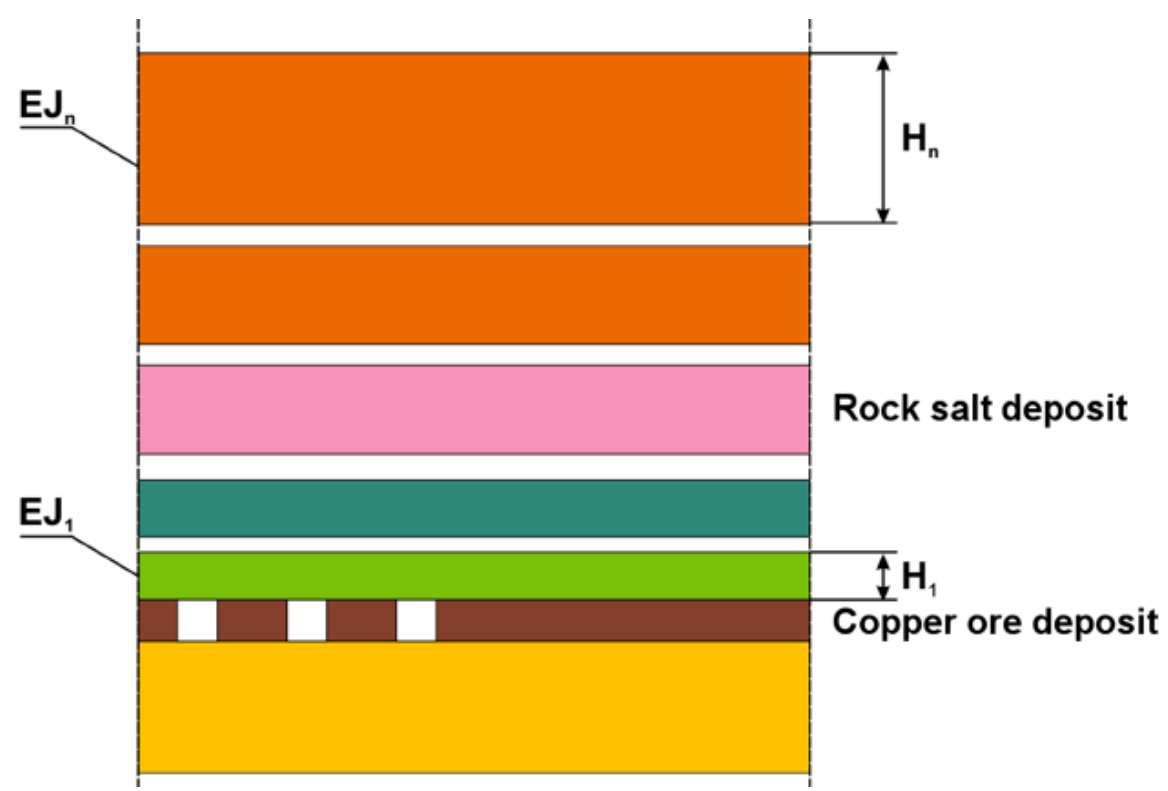

Fig. 9. Layer and block structure of the rock mass as a pile of rocks of diversified rigidity

Numerical tests carried out in Figure 9 of a block and layer model of the rock mass, with the presence of rock-salt, allow formulating of the following conclusions:

- the presence of a rock-salt in the ceiling of the deposit of copper ores exploited (area II-northern) is more a reason for other conditions in terms of safety than it is the case of carrying out exploitation in the rock mass without rock-salt formations (area I-central). Above all, this phenomenon is caused by relatively low values of strength parameters of salt formations, in particular tensile strength of salts, considerable thickness of deposits of salt and low cohesion between layers of salts and anhydrite,

- unfavourable geo-mechanical phenomena can occur in the case of discontinuities on the contact of salts and anhydrites, allowing formation of a large-scale deformation 
phenomenon. Computer simulations of the course of dynamic phenomena of this type indicate serious transformations in the state of stress in the salt massif, leading to further disintegration thereof as a result of implementation of destruction mechanisms, generated by excessive stretching and shearing,

- the numerical calculations show that the presence of rock-salt over the deposit of copper ores being exploited can slightly reduce the dynamic phenomena hazard near the front. Yet, such an increased level of safety on the front is accompanied by quite considerable decrease in level of safety at the height of the liquidation zone. This phenomenon is preceded by loosening on the contact of salt and upper anhydrites will develop both in the deposit of salt and in other layers as a result of transfer of the load and a sticky flow of the salt massif towards the post-exploitation cavern,

- impact of sticky properties of rock-salt, as a rheological layer, on safety of exploitation of the deposit of copper ores is generally slight,

- particularly unfavourable conditions to performing mining works will occur in areas with a thin rigid shelf of ceiling rocks (below $50 \mathrm{~m}$ ) where the thickness of salt is a few times higher $(100 \div 150 \mathrm{~m})$. In these areas high-energy dynamic phenomena (seismic shocks) should be expected.

The presence of rock-salt, as a rheological layer in the profile of the ceiling of the deposit being exploited of copper ores of the Fore-Sudetic Monocline, is a new problem, requiring comprehensive and deepened analysis, necessary to prepare new exhausting systems taking into account minimisation of hazards caused by the rock mass shocks.

Taking into consideration the above conclusions, it needs to be additionally noted that speeds of propagation of the seismic wave (generated by the rock mass shake) in the basic ceiling of the deposit of copper ores are very close to each other and are as follows:

- for dolomitic limestones: $4.5 \div 6.5 \mathrm{~km} / \mathrm{s}$,

- for anhydrite: $5.8 \div 6.5 \mathrm{~km} / \mathrm{s}$,

- for rock-salt: $3.5 \div 4.5 \mathrm{~km} / \mathrm{s}$.

In order to give an answer to the question whether the presence of the deposit of rock-salt in the amount of the deposit of copper ore in O.G. "Sieroszowice I" influences the flow capacity of the seismic wave towards the land surface, it needs to be answered that due to a substantial exploitation depth and similar to one another speeds of propagation of the seismic wave in the amount this impact shall be slight.

\subsection{Principles for Prevention of Crumps and Collapsing of Roofs Allowing Exploitation the Deposits of Salt and Copper Ore}

Due to a layer and the block structure of the rock mass in the area analysed and similar speeds of propagation of the seismic wave (generated by the rock mass shake) in the basic ceiling of the deposit of copper ores, the presence of the deposit of rock-salt does not have crucial impact on the flow capacity of the seismic wave towards the surface. However, in a situation where the deposit of salt exploitation excavations will be made, high-power shocks of the rock mass $\left(\left(10^{5} \mathrm{~J}\right)\right.$ generated by the exploitation of the deposit of copper ores will affect the stability of elements within the chamber and pillar system of exploitation with long-term ceiling stability. 
For this reason in order to limit harmful, mutual interaction of exploitation of copper ores and rock-salt the following are recommended:

- do not carry out simultaneous exploitation within the scope of occurrence of mutual influences,

- specify volume of optimum extraction of copper ore in the area of impact and influence of this exploitation on the condition of effort lying above the deposit of rock-salt,

- take into account forecasts as regards the seismic activity triggered by exploitation of copper ores, and in particular influence on salt excavations.

\section{Summary and Conclusions}

Undertaking, for the first time in the Polish mining industry, a simultaneous extraction of two mineral resource deposits, namely the deposit of copper ores and the deposit of rock-salt under the conditions of the Mining Area "Sieroszowice" in Legnica-Głogów Copper Belt, it was made possible to recognise in detail mutual influences of this exploitation in the aspect of mining safety.

The two-year period of tests conducted based on theoretical models, verified by comprehensive observations of the behaviour of the rock mass and the mining excavations in the deposit of copper ores and deposit of salt, allowed for preparing conditions suited to carrying out exploitation of both of these deposits ensuring conditions of safety for people and of protection of the land surface.

The forecasts of impact, in the first stage, of exploitation of the deposit of copper ores on salt excavations, and in the second stage, of exploitation of the deposit of salt on ore excavations were the basis for considerations and analyses. Analyses were carried out with reference to projects of further extraction of copper ores in the new concession for 2014-2063 and projects of exploitation of the deposit of rock-salt "Bądzów".

The most important results of considerations can be delivered in the form of the following conclusions:

1) Exploitation of the deposit of salt can adversely affect carrying out extraction of the deposit of copper ore. The scope of this impact for the deposit "Bądzów" has been determined as $70 \mathrm{~m}$ for the vertical component and as $50 \mathrm{~m}$ for the horizontal component. Current exploitation aims in the deposit of copper ore and the deposit of salt satisfy the condition of the safe vertical distance. Until 2021, in accordance with the schedule of mining works developed by the mine (Fig. 7), this condition may be deemed satisfactory. In subsequent years this condition needs to be taken into account when developing exploitation of the deposit of salt.

2) Analysis of past dynamic phenomena accompanying exploitation of copper ores under the conditions of OG "Sieroszowice I" demonstrated great seismic activity and strong dependence on the amount of, and energy of, shocks on intensity of extraction of the deposit of copper ore. It required determining respective principles for prevention of crumps and falls of roof as well as current observance thereof.

In the summary of conclusions formulated it is recommended to continue monitoring mutual interactions of exploitation of the deposit of copper ore and the deposit of rock-salt, which will 
allow further verification of theoretical considerations. It particularly recommended to extend the scope of observation with measurements of absolute shifts in salt excavations as well as of monitoring of dynamic phenomena caused by current exploitation.

\section{References}

Andrusikiewicz W. i in., 2012. Model rozcięcia i przestrzenne usytuowanie wyrobisk $w$ złożu solnym jako wytyczne do opracowania projektu technicznego eksploatacji - etap II. Fundacja Nauka i Tradycje Górnicze, Kraków.

Florkowska L., 2000. Numeryczne wyznaczanie stanu naprężenia w ścianie budynku poddanego wplywowi nieciagtych deformacji powierzchni. Arch. Min. Sci., Vol. 45, No 2.

Kłeczek Z., 1994. Geomechanika górnicza. Śląskie Wydawnictwo Techniczne, Katowice.

Kłeczek Z., 1999. Wytrzymałość soli kamiennej złoża LGOM w złożonym stanie naprężeń. Czasopismo Naukowo-Techniczne Górnictwa Rud CUPRUM, nr 11.

Korman S., 1958. Stan napięcia w górotworze pod wybieranym pokładem. Cz. I. Podstawy teoretyczne. Archiwum Górnictwa, t. 2, z. 3.

Monografia KGHM Polska Miedź S.A. Lubin 2007.

Popiołek E., 2009. Protection of Mining Areas. Wydawnictwo AGH, Kraków.

Popiołek E., Kłeczek Z. i in., 2011 i 2012. Określenie wzajemnych wpływów eksploatacji złoża miedzi $i$ złoża soli w warunkach KGHM Polska Miedź S.A. - etap I, II i III. Stowarzyszenie Naukowe im. Stanisława Staszica, Kraków.

Projekt zagospodarowania złoża soli kamiennej „Bądzów”. Opracowanie Chemkop. Kraków, wrzesień 2012.

Zeljaś D., 2008. Ocena geotechnicznych możliwości podziemnego składowania odpadów niebezpiecznych w złożu soli kamiennej LGOM. Praca doktorska, AGH Kraków. 